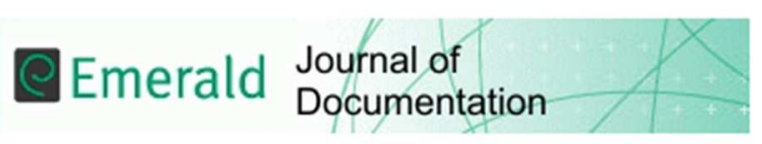

\title{
Australian motor sport enthusiasts' leisure information behaviour
}

\begin{tabular}{|r|l|}
\hline Journal: & Journal of Documentation \\
\hline Manuscript ID & JD-12-2015-0150.R1 \\
\hline Manuscript Type: & Article \\
\hline Keywords: & $\begin{array}{l}\text { information behaviour, information needs, information seeking behaviour, } \\
\text { leisure information, motor sport, Archives, Records management }\end{array}$ \\
\hline \multicolumn{2}{|c}{} \\
\hline
\end{tabular}

\section{SCHOLARONE ${ }^{\text {M }}$ \\ Manuscripts}




\title{
Australian motor sport enthusiasts' leisure information behaviour
}

\begin{abstract}
Introduction
The research reported in this paper is part of continuing research by the author into the information management challenges of community archives and its sustainability in Australia using the motor sport community as a case study (Joseph, 2015). Firstly, this research investigated the information management practices at motor sport community-based organisational levels at the historic car clubs, and the national and state offices of the Confederation of Australian Motor Sport Ltd (CAMS) (Author, in review-a). Secondly, it investigated what are the motor sport community's significant information assets (records and archives) (Author, in review-a) including what information individual motor sport enthusiasts required from CAMS (Author, in review-b).
\end{abstract}

This paper reports on the third aspect of this continuing research which, explored the leisure information behaviour of motor sport enthusiasts via an online survey completed by both competitors and officials in motor sport in Australia. The primary aim of this research was to examine the information behaviour of motor sport enthusiasts in Australia: what are their information needs; what information sources they consulted to fulfil these needs; and what information sources they used to share their interest in motor sport with family and friends. This study also tiptoed to explore enthusiasts' personal information management (PIM): what personal information resources they had and in what media format they held their information.

Information behaviour research has begun to examine the extensive time, effort, and resources individuals invest into their leisure activities, including information seeking, sharing, and use (e.g., Case, 2010; Chang, 2009; Skov, 2013). These leisure or non-work activities, including those belonging to serious leisure pursuits (Stebbins, 2007), can be deeply informational in nature, and involve complex information behaviour, including the development and maintenance of information management systems (Hartel, 2006). This study adds to this expanding body of research by exploring the leisure information behaviour of motor sport enthusiasts in Australia. This topic was chosen not only because it represents a gap in the literature, but also because motor sport enthusiasts require complex information resources in order to carry out this leisure activity safely. Motor sport is an extremely popular leisure activity in Australia, one with over 150,000 participants (CAMS, 2014, p.10) and which generates over $\$ 2.7$ billion dollars in revenue annually (CAMS, 2014, p.5).

As this research centres on the information behaviour of individual motor sport enthusiasts, it highlights their activities regarding information seeking, sharing, and use, and therefore does not explore information seeking from the car as an information source, or draw from the body language of enthusiasts at race events. Additional research is underway on the information needs of enthusiasts building their own racing car, which will be the subject of a separate paper.

This paper begins with an introduction to the motor sport leisure activity. Then the literature is surveyed on three topics: Stebbins $(2001,2007)$ serious leisure activity; information behaviour in leisure or non-work related activities; and work related information behaviour 
theories and models. The conceptual frameworks for this research are guided by: Savolainen's (1995b) ELIS model; Wilson's (1984, 1999, 2000) and Krikelas' (1983) general models on information behaviour; and Dervin's $(1976,2005,1992)$ information problem solving behaviour model. A primary theoretical contribution of this research is the preliminary motor sport information behaviour model.

The methodology section describes the design of the online survey, as well as the processes of data collection and analysis. This is followed by a presentation of the research findings and discussion of enthusiasts' information behaviour against the literature reviewed. The conclusion discusses the significance and limitations of the research, and identifies topics for future research.

\section{Motor sports in Australia}

Active participation in sporting and recreation activities as well as attending sporting events as spectators is an important part of the Australian lifestyle. Between 2011 and 2012, 65\% of Australians participated in sporting activities (Australian Bureau of Statistics, 2012, p. 11).

Motor sport is one of the top ten ranked sports for Australia in terms of total attendance, with approximately 1.5 million attendees annually, and is reported to be the fourth most watched sport in Australia (Australian Bureau of Statistics, 2012, p. 30). A 2013 survey commissioned by the regulator of motor sport in Australia, the Confederation of Australian Motor Sport Ltd (CAMS) (hereon CAMS survey) reported that: 150,000 Australians participate in fourwheeled motor sport across Australia, of these participants: 55,339 are competitors only; 3,619 compete and officiate; 17,419 only officiate; and 76,775 are other club members (CAMS, 2014, p. 10). The CAMS survey also reported that in 2013 the Australian motor sport generated $\$ 2.7$ billion in revenue and 16,181 jobs (CAMS, 2014, p. 5).

Motor sport involves competition events 'in which an automobile takes part and which [have] a competitive nature or [are] given a competitive nature by the publication of results' (CAMS, 2014, p. 6). The drivers are referred to as competitors and they are usually supported by a team of track and off track personnel such as: pit crew members, engineers, trades people, finance managers, sponsors, doctors, and dieticians. Some team members are paid whilst others are volunteers. The competitors and pit crew team supporting the driver can be professionals or amateurs usually, depending on which level of racing they compete in. Motor sport, particularly motor racing, can be described using a metaphor of a pyramid of levels of participant involvement, as presented in Figure 1.

\section{[Insert Figure 1]}

In motor racing the top of the pyramid is Formula One, commonly referred to as F1. It comprises 20 to 25 professional participants who drive the vehicles. The next level of race drivers are professional international drivers, approximately 2000 of whom compete in events like the Le Mans, Indy Car, and V8 Supercar series. The national level competitions have approximately 20,000 professional drivers. They compete in the approximately ten motor national racing (circuit) competitions held annually in Australia.

The fourth level down the pyramid - the focus of this research - is the state and club level amateur drivers (all disciplines) and amateur volunteers. According to CAMS (2014), 'the Australian motor sport industry includes and supports: 334 tracks and venues; 1,391 clubs and 6,247 events' (p. 12). 
The lower level of the pyramid comprises the fans, spectators, and social participants of motor sport. Apart from the drivers/competitors in motor sport, there are '17,419 licenced volunteer officials in Australia who are responsible for running the majority of motor sport events' (CAMS, 2014, p. 2). The reliance on volunteers in various capacities for officiating, administering, and promoting the sport is prevalent internationally. A proportion of the top level officials in the sport are paid whilst the remainder are volunteers who do it for their love of the sport at their own cost, free time, and free will.

Land-based motor sport in Australia is predominantly governed under the jurisdiction of the Confederation of Australian Motor Sport Limited (CAMS). CAMS is a 'not-for-profit member-based organisation focused on the development, regulation and administration of motor sport across Australia' (CAMS, n.d.). In 2013, there were 460 car clubs affiliated to CAMS and they organised '4,311 events, with over half of these being non-competitive social events' (CAMS, 2014, p. 24).

In summary, involvement in motor sport can be divided into professional, amateur and volunteer groups. The information behaviour of motor sport enthusiasts studied in this research pertains to participants who are amateurs and volunteers, and not professionals. The focus is on both the amateur drivers/competitors and amateur volunteers in various officiating and supporting roles in motor sport, at motor sport clubs and state levels, as shown in Figure 1. Here on, this subject group will be referred to in this paper as motor sport enthusiasts or enthusiasts. Those who follow the sport as fans or spectators are not covered in this research. Further, this research is focused on the four wheeled motor sport and not motor cycles but acknowledges that similarities apply to the motor cycles. The research participants in this study are competitors and/or volunteers at CAMS and/or its affiliated car clubs in Australia.

\section{Literature review}

This section outlines the literature on three relevant topics: 1) leisure and serious leisure by Stebbins (2001; 2007); and information behaviour in 2) leisure and 3) non-leisure settings.

\section{Motor sport from a serious leisure perspective}

Sociologist Robert Stebbins (2007) defines leisure 'as uncoerced activity engaged in during free time, which people want to do and, in either a satisfying or a fulfilling way (or both), use your abilities and resources to succeed at this' (p. 4). Stebbins (2007) categorises leisure into: casual; serious leisure and project-based leisure.

Serious leisure, in particular, is relevant to this study. This phenomenon is defined by Stebbins $(2007$, p. 5) as the

systematic pursuit of an amateur, hobbyist, or volunteer core activity that people find so substantial, interesting, and fulfilling that, in the typical case, they launch themselves on a (leisure) career centered on acquiring and expressing its special skills, knowledge, and experience.

According to Stebbins, serious leisure involves three participant types: 1) amateurs; 2) hobbyists and 3) volunteers, and has these distinguishing qualities:

- there is a need to persevere and find a leisure career;

- involves significant personal effort using acquired knowledge,

- requires training, experience or skill;

- has durable benefits plus a unique ethos that creates a spirit of community; and 
- participants identify strongly with their chosen pursuits (2007, pp. 11-12).

Amateur sports activities can constitute serious leisure: examples include research on runners (Major, 2001) and swimmers (Hastings \& Cable, 2001). Motor sport meets the above criteria of serious leisure, and participants use terms common in serious leisure such as 'interesting', 'stimulating' and 'pleasant' to describe their involvement in the sport. Enthusiasts also participate in motor sport during their free time and out of their free will and choice, another feature of serious leisure participation (Stebbins, 2007).

In motor sport, the worlds of the professionals, amateurs and volunteers are interconnected, however there are clear boundaries as Cox and Blake (2011, p. 206) point out:

professionals set standards of performance that amateurs respect, professionals often train amateurs, while amateurs are often a key, critical audience for professionals. Amateurs perform for the same public as the professional, to a certain extent, as well as for a collegial audience of fellow practitioners (and friends and family).

Stebbins (2001, p. 5) describes volunteering as

a helping action of an individual that is valued by him or her, and yet is not aimed directly at material gain or mandated or coerced by others. Thus, in the broadest sense, volunteering is an uncoerced helping activity that is engaged in not primarily for financial gain and not by cohesion or mandated.

This section outlined the concept of serious leisure in relation to motor sport activities. The next section reviews existing research on information behaviour in leisure settings.

\section{Information behaviour in leisure activities}

Though a small but growing body of research documents information seeking, sharing, and use in serious leisure activities, there has so far been no research on the information behaviour of motor sport enthusiasts. Existing research on information in leisure settings has examined the following: leisure reading (Ross, 1999); genealogy and family history (Fulton, 2009; Yakel, 2004); gourmet cooking (Hartel, 2006, 2010); knitting (Prigoda \& McKenzie, 2007); photography (Cox et al., 2008); backpackers (Chang, 2009); rubber ducks collection (Lee \& Trace, 2009); online museum visitors (Skov, 2013); quilting (Gainor, 2009); coin collection (Case, 2010); food blogging (Cox \& Blake, 2011); and music records collectors (Margree et al., 2014). Table 1 summarises the literature review in leisure activities: identifies researchers in the discipline (Column 1); identifies the type of leisure activity they researched (Column 2); uses Stebbins participant types (amateur, hobbyist and volunteer) in serious leisure to categorise participants (Column 3); provides a snapshot of the research aims (Column 4); and the research methodologies employed (Columns 5 to 8).

\section{[Insert Table 1]}

In the literature reviewed, the majority of studies refer to participants as hobbyists (e.g., Yakel, 2004), while only two refer to their activities as those of amateurs - Cox et al's (2008) research on photography, and Fulton's (2009) study on genealogy.

Some of these studies included aspects of information management in their findings (e.g., Cox \& Blake, 2011; Hartel, 2010; Yakel, 2004), for instance by documenting what personal information participants had and in what formats. None of this research, however, measured 
whether or not participants' needs around information management were being met, whether they needed assisstance, or whether they were satisfied with their current information management strategies. This study aims to fill this gap as well with respect to the information behaviour and management of motor sport leisure enthusiasts.

Whilst surveying the literature on information seeking behaviour in leisure activities it was observed that the seminal literature in work related or non-leisure information seeking behaviour was referenced considerably, hence it was reviewed next.

\section{Information behaviour in non-leisure settings}

Given the research focus on the information behaviour of motor sport enthusiasts, it is necessary to review the allied literature that examines information behaviour, information needs and information seeking theories and models (Case, 2002, 2012; Fisher, Erdelez, \& McKechnie, 2005). As a first step, definitions of the key terminology in this discipline are reviewed and its adoption for the research is clarified.

The author agrees with Cole that 'information need is the motivation people think and feel to seek information' (Cole, 2012, p. 3). Also that information need is the 'state of uncertainty recognised by the individual user' (Henefer \& Fulton, 2005, p. 226). Wersig (1979, 1985) describes this as the problematic situation. Belkin expands on the description of this problematic situation as the Anomalous State of Knowledge (ASK), which he describes as an inadequacy in the user's state of knowledge with respect to a problem or task that prevents them from resolving the problem or task at hand (Belkin, 1980; Belkin, Brooks, \& Oddy, 1982). This inadequacy in the user's state of knowledge is identified as the gap (Dervin, 1992; Dervin \& Foreman-Wernet, 2003). In her 'sense-making' theory Dervin defines an information gap to a state in which a person perceives a gap in their existing knowledge structure in order to make sense of the situation, problem or task at hand (Dervin, 1992; Dervin \& Foreman-Wernet, 2003). Wilson's (2005) models emphasise what drives the information need of a user, which segues to the subsequent topic on information seeking behaviour.

Ellis defines information seeking behaviour as the complex patterns of actions and interactions that people engage in when seeking information of whatever kind for whatever purpose' (Ellis, 2003).

Information seeking behaviour models describe the process stages and/or the activities performed at each stage in a manual and/or in an electronic system setting. Examples of research in this setting include the work by (Ellis, 1984, 1989, 1993, 2003; Kuhlthau, 1988, 1993, 1999, 2004, 2005). They do not describe the users' interactions with the system. In contrast information search or information retrieval behaviour refers to the users' interaction with an electronic system to seek/search/look for their information. Information search and retrieval behaviour usually includes information search processes (ISP) (Bates, 1979, 1984, 1989; Debowski, 1997; Ingwersen, 1982, 1992, 1996, 2001, 2005; Joseph, 2010; Maclean \& Shipman, 2003; Marchionini, 1995, 2008; Marchionini \& White, 2007; Saracevic, 1997; Spink \& Saracevic, 1997). This research is focused on the user-related and not the systemrelated information seeking behaviour, as the aim is to explore motor sport enthusiasts' current information behaviour. It is acknowledged that enthusiasts would use electronic systems to seek and search for information to fulfil their information needs. However, the objective is to find out what are these system sources and understand what types of information are sought, but not how they interact to search and retrieve information from these sources. As such, this research is focused on how the enthusiasts' environmental setting 
in the motor sport recreational context influences their information needs and what information sources they sought to fulfil their information needs.

Given the user-centered approach that this research aims to embark on, it is posited in the wider information behaviour and information need subject disciplines. Consequently, the general and seminal information behaviour models by Dervin (1992), Krikelas (1983) and Wilson $(1984,1999,2000)$ were selected to provide a conceptual framework for this research as it offers a methodology to study the problems with information needs and seeking from the users' perspective.

Wilson's (1984, 1999, 2000) and Krikelas'(1983) models are described as general models on information behaviour (Case, 2005; Fisher et al., 2005). Wilson's (1984, 1999, 2000) models emphasise the context of information seeking: for instance, what drives the information need of a user?, whilst Krikelas' states that 'information seeking is a response to what the individual perceives as an immediate need' (Henefer \& Fulton, 2005, p. 226). Krikelas (1983) identifies three activities as foundations of his information behaviour model: 1) information gathering, 2) information giving, and 3) information seeking. Dervin's sensemaking methodology metaphorically presents how people in their everyday life make sense of their world in different situations in a space - time continuum (Dervin, 1976, 2005, 1992; Dervin \& Foreman-Wernet, 2003). They acknowledge their information need, subsequent gap in their knowledge and make efforts to bridge this gap by seeking for information using information sources available to them (Dervin, 2005, 1992; Dervin \& Foreman-Wernet, 2003; Savolainen, 1995b). Savolainen (1995b) provides a good overview of Dervin's sensemaking theory, which is referred to in his everyday life information seeking (ELIS) behaviour model reviewed next.

Savolainen's (1995b, p. 268) ELIS model was reviewed to assess its applicability to this research. Savolainen (1995b, p. 270) interviewed 22 people from Tampere a Finish town, from two social classes (11 industrial workers and 11 middle class teachers) to develop the ELIS model. The ELIS model examined how an individual's social and cultural circumstances influenced their way of life (order of things) and their mastery of life (keeping things in order) (Savolainen, 1995b). In lay man's terms, the ELIS model posits that an individual's social, cultural, financial circumstances including their values and situations in life, affect their way of life in terms of how much time and money they spend on their work and importantly in their leisure activities. It also affects how they order their life so that they are positioned to manage their lifestyle and be able to address problems and problematic situations in life (mastery of life). Savolainen (1995b, p. 268) identified four types of problem solving behaviours for addressing everyday life information seeking problems: 1) optimisticcognitive; 2) pessimistic-cognitive; 3) defensive-affective and 4) pessimistic-affective.

The ELIS model has been referenced in other leisure information seeking behaviour settings like recreation, leisure and collecting activities: coin collection (Case, 2010); gourmet cooking (Hartel, 2006, 2010); genealogy and family history (Yakel, 2004); online museum visitors (Skov, 2013); pleasure readers (Ross, 1999); and music record collectors (Margree, MacFarlane, Price, \& Robinson, 2014).

In the current research, the motor sport enthusiasts' decision to be involved in this sporting and recreation activity is a given. Hence, it can be assumed that their social, cultural, financial, values and situation in life support their involvement in motor sport. What is unknown is about their information needs and what information sources they use to fulfil those needs. Further, what information resources they have; in what format they hold their 
information; and importantly if they need help with their personal information management. We also know little about how they share information about their sport with family and friends or what information sources are used for such activities.

In summary, the theoretical concepts and conceptual framework of this research are guided by: Savolainen's (1995b, p. 268) ELIS model; Wilson's (1984, 1999, 2000) and Krikelas'(1983) general models on information behaviour; and Dervin's information problem solving behaviour model (Dervin, 1976, 2005, 1992; Dervin \& Foreman-Wernet, 2003).

Although, personal information management activities like acquire, organise, maintain, retrieval, use and control are entwined with these theoretical concepts; it is not the foci of this research (Jones \& Teevan, 2007). Hence, the omissions of this literature review in this paper.

\section{Research questions and methodology}

The primary research question of this study is to explore:

PQ) What is the leisure information behaviour of motor sport enthusiasts?

The following six secondary questions were developed to explore answers to the primary question.

1. What are the information needs of individual motor sport enthusiasts?

2. How they seek this information?

3. What information sources they turn to?

4. How they share their information?

5. What personal information about their leisure activity do they have?

6. What are their overall satisfaction levels about their information seeking and management efforts?

Generally scholars researching information behaviour employ interviews, participant observation, and online surveys. Most popular was the use of in-depth semi-structured interview techniques (Brine \& Feather, 2010; Chang, 2009; Cox \& Blake, 2011; Cox et al., 2008; Fulton, 2009; Gainor, 2009; Hartel, 2006, 2010; Lee \& Trace, 2009; Margree et al., 2014; Prigoda \& McKenzie, 2007; Ross, 1999; Yakel, 2004). Participant observation was done in the coin collection (Case, 2010) and knitting (Prigoda \& McKenzie, 2007) serious leisure activities. Online surveys were used in the online museum visitors (Skov, 2013) research only.

An exploratory study was chosen as little is known about the leisure information behaviour situation of motor sport enthusiasts. There is currently no research on enthusiast's information needs, problems and/or successes, or what information assets they gather, share or manage.

A postpositivist and inductive qualitative research approach using empirical elements from the motor sport community was employed (Creswell, 2013, p. 24).

\section{Survey design}

To reach the broadest possible sample of respondents within the motor sport community in Australia, an online survey research tool was chosen for this study. The survey was designed using the Qualtrics software and included both quantitative and qualitative questions; this was 
done to ensure that qualitative data could help to explore issues that cannot be quantified (Gorman \& Clayton, 2005, p. 14).

The researcher's involvement in motor sport over the past three years as a volunteer scrutiny clerk offered insight into the information behaviour of enthusiasts, and therefore supported the development of the survey tool used in this research. Feedback on the survey's design was collected through interviews with a key informant with over 40 years of involvement in motor sport, and from 12 pilot participants who completed the draft survey. Based on this input, changes and refinements to the tool were made. Final piloting of the completed survey took place at race events held in Melbourne in March 2014: eight participants took part at this stage and their responses are included in the final dataset. Based on this second pilot, it was decided that data collection would best be conducted online instead of in person at race events, due to the distracting and loud nature of these environments.

The survey consisted of 33 questions, separated into five groups, as noted in Table 2. A full list of the online survey questions can be found in Appendix 1.

\section{[Insert Table 2]}

This paper reports on the survey questions 1 to 20 only. The remaining questions 21 to 33 are subject of another paper.

\section{Data collection}

Following ethics approval for this study, a link to the online survey from Qualtrics was advertised electronically to promote participation by enthusiasts. A link to the survey was distributed in a CAMS press release using the following media:

1. the CAMS website;

2. a tweet on the CAMS twitter page;

3. the CAMS online magazine;

4. Facebook, including:
a. the CAMS Facebook site;

b. a Facebook site set up for this research, entitled

Australian Motor Sport History Archives - AMSHA; and

c. the Facebook sites of various car clubs in Australia.

5. motor sport forums:

a. Autosport The Nostalgia Forum (TNF); and

b. Speedwest forum hosted in WA.

A month and half from 15 March to 30 April 2014 was allowed for participation in the survey. A total of 120 people started the survey and 81 (67.5\%) completed the survey with an attrition rate of $39(32.5 \%)$.

The attrition rate could be attributable to participants' survey fatigue; loss of interest; and/or failure to complete the survey within the timeline. This varied the response rate for some questions. A further reason for this variance could be attributable to the survey design, whereby questions incorporating filters and contingencies were skipped, depending upon an individual's response.

\section{Data analysis}

An inductive data analysis approach was adopted for both the quantitative and qualitative survey data. Descriptive statistical analysis was generated using the Qualtrics software, which 
was most useful for reporting on the percentages for the multiple choice answers. The Nvivo analytical software was used to code and analyse the qualitative data for Q16 only. Content analysis was initially used to analyse the textual responses for Q16, which were subsequently coded against the 16 topics developed by the researcher. Given the key informant's motor sport experience, he was tasked with verifying the researcher's coding against the 16 topics.

The informant's input led to suggestions to aggregating some of the initial sub-topics into higher level topics. The final 12 topics against which the data was coded are listed in Column 2, Table 8.

The remaining text based questions were analysed manually as they contained limited information and did not require detailed coding. Both content analysis followed by thematic analysis was used to analyse the remaining textual data (Braun \& Clarke, 2006).

\section{Findings}

The findings for questions 1 to 20 are reported here in three segments: participants' demographic data; their information needs and seeking behaviour; and what personal information about the sport they had. This section presents the raw data about the findings, while the discussion of these findings is presented later under the discussion section.

\section{Demographic data about the motor sport enthusiasts}

One hundred and twenty participants started the online survey; 109 males and 11 females. The largest group was aged between $60-69$ years old (32\%), followed by $50-59$ years old (21\%). Eighty-seven (73\%) were motor sport competitors whilst $33(28 \%)$ were not and were likely volunteers who performed the role of officials for the sport.

The 74 participants who identified themselves as motor sport competitor were from all nine disciplines of motor sport as shown in Table 3.

\section{[Insert Table 3]}

The two largest disciplines in this survey match those found in a survey by CAMS. According to the CAMS survey, 'Circuit and Speed are the two largest motor sport disciplines in Australia, in terms of participation, direct output, value add and employment. Collectively, these two disciplines account for over 60\% of Australian motor sport industry output' (CAMS, 2014, p. 14).

One hundred and four (104) participants categorised their involvement in motor sport as volunteers, spectators, and as club committee members, as presented in Table 4.

\section{[Insert Table 4]}

The volunteers performed the roles of officials as indicated in the first row of Table 4 but also other roles such as: pit crew; track preparation; conduct of the events like the hill climb; race commentary; road closure; and event organisation.

The option of being involved as a competitor was omitted in Q7 as this question was asked in Q4 Are you or were you a motor sport competitor? However, a dozen responses in the specify other involvement for Q7 were as competitors. 
It was observed that the enthusiasts were often involved in their sport in more than one role. Usually, the competitors also volunteered to perform other officiating roles such as scrutineer, flag marshal, pace car driver, and in other roles at the race event. However, the decision on the role assumed at the race event by an individual is made prior to the event to ensure conflict of interest and roles are omitted. Hence, if the enthusiast is competing, they will not officiate at that race event. Stebbins (2007, p. 34) describes this phenomenon of assuming multiple roles in the same leisure as mixed serious leisure:

This involvement in two or more types or subtypes of serious leisure that, together constitute for the participant an integrated pursuit of a more encompassing free-time activity than either of the two pursued alone.

Sixty-one participants $(59 \%)$ have had an interest in motor sport for more than 30 years. The majority reported they developed an interest in motor sport during their early childhood.

They were mostly introduced to motor sport by family and friends. Often a close relative, such as a father was a motorsport enthusiast, and a common thread was attending motor sport events with family and friends. Reading about motorsport and watching television further enhanced their interest. The following quotes illustrate how the respondents developed their interest in motor sport:

Early childhood, built my first race car called Norton Special.

My father took me to a meeting in Tasmania in 1961 and I saw Jack Brabham driving the Cooper Climax and that started my interest in motor sport.

Parents were both competitors in motorsport when I was growing up. My uncle got me involved in volunteering.

My parents took me along to the Showground Speedway many times as a lad, and later to many circuit races at Oran Park. This sparked a lifelong interest and I attended meetings at Warwick Farm, Amaroo, Oran Park etc. Became a motor sport official when a friend invited me to help out in the tower at Amaroo in the 1990s.

My brother introduced me to pit crewing and from there I took an interest also in officiating.

I was just attracted to the colour, action and noise when visiting a local speedway when I was a small child - it grew from there.

In summary, these findings align with a CAMS survey that reported ' $80 \%$ of people surveyed said 'being with family and friends' is an important reason why they are involved' in motor sport (CAMS, 2014, p. 3). This is also the rationale provided by other sociologists (Dannefer, 1980, 1981; Stebbins, 2007) on how and why leisure activities are pursued.

Thirty-three participants (32\%) stated that they spend between 10 to 50 hours in a week engaged with motor sport activities. Though participants indicated that motor sport involves a large commitment of time and money in their lives, they appear quite satisfied with both: over $90 \%$ of respondents were either "very satisfied" or "satisfied" with their time investment in motor sport, while over $75 \%$ were "very satisfied" or "satisfied" with the way they spent their money in the sport (see Figure 2). Investing heavily in motor sport is not unusual, as a survey by CAMS found: 'on average, motor sport competitors spend between $\$ 12,000$ and 
$\$ 15,000$ a year on motor sport activities and \$60,000 on motor sport vehicle purchases and initial modifications' (CAMS, 2014, p. 4).

Participants were also generally satisfied with the membership services they received from their various motor clubs, as shown in Figure 2; over half noted that they were either "very satisfied" or "satisfied".

\section{[Insert Figure 2]}

\section{Information Needs and Seeking Behaviour}

This section of five questions aimed to investigate enthusiasts' information needs and their information behaviour.

Table 5 presents the information needs of enthusiasts, ranked by their highest information need.

\section{[Insert Table 5]}

The top 3 information needs of motor sport enthusiasts occur before the race event and are: 1) what are the upcoming competitions $(80 \%), 2)$ competition related information $(69 \%)$, and 3 ) the technical information $(64 \%)$ they require getting their cars ready for the event.

The 'other' information needs that were reported under the last option in Table have been merged with the responses for Q16 and are reported later under Q16.

Table 6 presents the information sources that were rated highly by enthusiasts to keep themselves informed and updated about motor sport.

\section{[Insert Table 6]}

The top five methods and information sources used by enthusiasts to keep themselves informed were by using: print and traditional media sources (including radio, television, newspapers, magazines and books); human sources; event organisers; social media tools; and web sources.

\section{[Insert Table 7]}

In Q14, ninety participants stated that they share information about their interest in motor sport with family, friends and fellow motor sport enthusiasts. Subsequently, in Q15 presented in Table 7, 69 participants $(77 \%)$ stated that they share this information by email; 49 participants (54\%) via Facebook; and 42 participants (47\%) use SMS text messages to share this information.

In the Other, please specify option on Table 7, fourth row, participants stated that they share their interest in their sport by: talking about it via face-to-face chats, phone, online forums, and tweeting, predominantly. Few also publish articles about the race events, broadcast on the television and on websites they manage as webmasters.

Question 16 asked enthusiasts: Q16.1) to describe what were the last three information needs they had; Q16.2) which information sources they checked to fulfil this need, and Q16.3) to rate their satisfaction levels when fulfilling these needs. 
The data for the first two parts of Q16 were textual, hence inductive analysis was employed using the Nvivo software to group the data into information themes from which topics for each information theme were developed. Whilst initially coding the data, it was observed that the emerging themes frequently matched with the seven information needs topics developed and stated in Q12 (see Table 5, Column 1), and presented below:

1. technical information;

2. what are the upcoming competitions;

3. registration information for competitions;

4. about the course itself;

5. logistics information;

6. competition information; and

7. social events.

Hence, it was decided to reuse these topics where applicable but expand on the description for each topic from the new data. Five new topics were identified:

8. officials' information;

9. general information;

10. historical information about motor sport;

11. meeting dates for CAMS or clubs; and

12. event organisation.

In total, the information needs reported in Q16 were categorised into these 12 topics. A new node in Nvivo was created for each topic. Table 8 lists each topic with a detailed description and ranked by the topic with the most references.

\section{[Insert Table 8]}

In the second part of Q16 (Q16.2), participants were asked to state the information sources they checked or used to find the information they needed. Again, these textual data were exported from the Qualtrics software into the Nvivo software for qualitative analysis. Once again, during the data analysis it was observed that the information sources stated in Q13 matched most of the responses. Hence, nodes for each of these 15 themes were developed in Nvivo and were used to code and categorise the information sources, as presented in Table 9.

\section{[Insert Table 9]}

In the final part of Q16 (Q16.3), participants were asked to rate their satisfaction level when fulfilling their information need. Ninety-two participants responded to this question and generally they were satisfied in fulfilling their information needs.

\section{Personal information management}

The aim of this set of questions was to find out what personal information about motor sport individual enthusiasts collected or had at home, in what format these contents were, if they were satisfied with how they are currently managing this information, and lastly if they would like assistance managing this collection.

Table 10 presents the responses to the question, what information about motor sport do you have at home? 
[Insert Table 10]

The four top responses regarding participants' personal information about motor sport at home included photos, club newsletters, trophies and memorabilia, and competition results. Under the category of Other, participants specified that these resources included: race programmes, library materials (books, videos, DVDs, magazines), photocopies of newspaper clippings of motor sport events, officials' information, and information about past events (maps, routes, regulations).

These collections include the following types of records:

- permanent value archival records (photographs, trophies, memorabilia, specifications about their cars, certificates of awards);

- records of temporary short-term value (competition registrations, race results); and

- records that are ephemeral (copies of originals hopefully held at their car clubs, CAMS or by cultural institutions: library materials, magazines, maps, race programmes).

The media and format of these personal information resources are mostly held in a combination of paper and electronic formats $(65 \%)$, whilst $21 \%$ is in electronic format and $13 \%$ is paper based.

The enthusiasts reported that they were generally satisfied (47\%) with their management of personal information about their interest in motor sport at home, whilst $8 \%$ indicated they were "Somewhat Dissatisfied" and 0.4\% were "Dissatisfied". Also in Q20, 63\% responded that they do not require advice or assistance managing their personal information assets.

\section{Discussion}

The objectives of this research were to explore the information behaviour of motor sport enthusiasts. Findings on the information behaviour of motor sport enthusiasts led to the development of the preliminary motor sport information behaviour model presented in Figure 3. An explanation and discussion of this model derived from the seminal theoretical models by Wilson (1984, 1999, 2000), Krikelas (1983), Dervin (1992), and (Savolainen, 1995a, $1995 \mathrm{~b}, 1995 \mathrm{c})$ is presented next.

\section{[Insert Figure 3]}

Parallels can be drawn from the four factors that Savolainen (Savolainen, 1995a, 1995b, 1995c) identified as affecting peoples' everyday life information seeking behaviour in the ELIS model. In this study, it can assist in explaining how people select motor sport as their hobby and therefore their information seeking behaviour. Each of these parallel factors as it relates to motor sport is explained next. Enthusiasts are comfortable with the values and attitudes on how the sport operates, its impact on the environment and the personal risk racing entails. Motor sport as a hobby requires investment in capital and money to buy, hire, maintain, store, repair, register the car and participate in events, travelling to participate in race events outside the county, etc. Social networks such as family and friends involvement in motor sport also have an influence in developing one's interest in motor sport, as indicated in the survey. One's current situation in life like their health affects their participation in motor sport. Enthusiasts are required to pass rigorous medical test annually to be eligible for 
renewing their CAMS licence to participate in motor sport. These factors affect those who decide to take up motor sport as a hobby, thereby impacting on how they spend their time and money.

The motor sport leisure activity environment is the context that triggers the information behaviour for motor sport related information for enthusiasts. It is in this environment enthusiasts gather, share and seek information. It is also the context of information seeking that Wilson's $(1984,1999,2000)$ models emphasise; 'what drives the information need of a user?' Enthusiasts' interest and involvement in motor sport drives their information needs about their cars and the events they participate in.

Within this context of the motor sport information environment, enthusiasts were observed engaging in three activities: 1) information gathering, 2) information sharing, and 3) information seeking. These activities are described as foundations of Krikelas' information behaviour model (Krikelas, 1983).

The survey data indicated that enthusiasts gathered information about motor sport such as photographs, club information and memorabilia, listed in Figure 3. Some of this information is likely to be copies of ephemeral value and the original is hopefully maintained by their clubs like minutes of club meetings or club newsletters. However, their collection of photos, memorabilia and certificates are likely to be originals and are records of archival value. Future research about their personal information collection and an appraisal exercise of the contents needs to be undertaken to categorise it as records of ephemeral, temporary and permanent archival value. Also, future research, on how enthusiasts managed their personal information is required, these findings need to be incorporated into the preliminary motor sport information behaviour model.

They also shared their information primarily via emails $(69 \%)$ and via Facebook $(49 \%)$. Although, the survey did not ask details about what information they shared, it is reported from the author's involvement in motor sport that enthusiasts uploaded photos and comments about their performance, opinions, and interesting happenings about the race events on their personal websites, Flickr, FaceBook, YouTube, via text messages and emails. Photos were used primarily compared to words when updating family and friends. Race film footage from their GoPro cameras are uploaded on social media websites like FaceBook and YouTube to share and report racing experiences, especially when there are accidents.

Lastly, enthusiasts needed information about their sport, which created their information need. Krikelas' states that 'information seeking is a response to what the individual perceives as an immediate need' (Henefer \& Fulton, 2005, p. 226). Enthusiasts' information needs are identified in Table 8 . There is a strong need for information relating to the race event for both the competitors and volunteers of the sport. Both groups want to know everything about the event: when, where, what time, and what format? Next, these groups have a need for logistics information about how to get to the venue, travel and accommodation related information. Once at the race event their information needs varies. Officials need information related to their officiating roles. Whilst competitors require competition information about the track and weather conditions, when and where are their driver's briefings and scrutineering inspections, times for their individual their race events and about their race results. The need for technical information by competitors ranked second after event information. Competitors needed technical information to fix, maintain, repair, restore, upgrade and modify their cars or their team's car. In sum, the findings indicated that enthusiast' tasks triggers their information need and search behaviour (Bystrom, 2005; Bystrom \& Hansen, 2005; Bystrom \& Jarvelin, 
1995; Vakkari, 1999, 2003). Hence, their information need varies according to their tasks or problem solving needs. The importance of task driving the information need in leisure pursuits was noted in the leisure of backpackers (Chang, 2009), as well. However, this notion of task was not identified by other scholars researching leisure information seeking behaviour (Case, 2010; Cox \& Blake, 2011; Hartel, 2006; Lee \& Trace, 2009; Yakel, 2004).

Dervin's sense-making methodology was also observed in enthusiasts' information need, the subsequent gap in their knowledge and their efforts to bridge this gap by seeking information using information sources available to them (Dervin, 2005, 1992; Dervin \& Foreman-Wernet, 2003; Savolainen, 1995b). Savolainen describes these activities in Dervin's sense-making methodology as the problem solving behaviour in his ELIS model, as shown in Figure 3.

\section{Summary}

In summary, the findings raised awareness that enthusiast required information at three different stages of their motor sport leisure activity: before; during and after their race events. It was observed that greater information is required before the race event as there is a need find out when and where the upcoming race events are; what is the format of the race event (speed, regularity, etc); how to register for the event; what are the social events organised (when, where, what); and the logistics of getting themselves, family, pit crew and their competition car to the event. Then there are the technical information required for the race event: what are the race regulations and technical specifications that need to be adhered; is the car mechanically ready for racing; does it meet the scrutineering standards; when and where can the car be scrutineered; and is the car safe for racing. Again, some of this information is again required by the enthusiast at the race event at the track depending on how he/she and the car perform at the event. For example, if the enthusiast meets with an accident or if his car breaks down, his information needs and the sources he consults on track takes a new dimension if the decision is made to fix the car and continue racing. Once the race event is over, enthusiasts share, report and discuss their racing experiences with friends, family and fellow enthusiasts using different information sources.

Further, the findings confirm that enthusiasts use a variety of information sources, more electronic than paper-based sources. They relied heavily on the internet based information sources: firstly their club's website; secondly CAMS website; and thirdly the Google search engine. They are also aware which information source they need to select depending on their information need. This observation was made when participants were asked to describe what their last three information needs in Q16 were and which information sources they consulted. Enthusiasts were observed to seek race event specific information from the event organisers who are generally their car clubs by referring to the club's newsletters, magazines, websites, Facebook sites, and email communication. For licence and race regulations specific information they consulted the CAMS website understandably as their race regulator. These findings attest the quality of the information sources enthusiasts are using to satisfy their information needs.

In the current research, when enthusiasts have an information need they used electronic and human sources to fill their gaps. They are aware and have access to a number of information sources, which mostly satisfy their information need. Human sources ranked second amongst enthusiasts to keep themselves updated and informed about their motor sport (Savolainen \& Kari, p. 420). Dervin reported in 1976 a similar finding in her research stating that citizens in their everyday life information seeking consulted peer networks comprising family and friends to fulfil their information needs (Dervin, 1976). A few researchers reported that human sources ranked higher in their research in the ELIS model (Chen \& Hernon, 1982; 
Dervin, 1976; Savolainen, 1995a, 1995b, 1995c). Similarly, in the leisure information behaviour research reviewed in Table 2, the findings indicated participants consulted their peer networks to keep themselves informed or when they had questions related to their hobbies (Chang, 2009; Gainor, 2009; Lee \& Trace, 2009; Prigoda \& McKenzie, 2007).

It is interesting that in the $21^{\text {st }}$ century this trend continues when people have access to electronic technologies. However, in this research participants could be contacting their personal peer networks using mobile technologies more than in person. It is not possible to conclusively rank which of these options they prefer from the survey responses.

The information needs of the enthusiasts are dynamic depending on what aspects or tasks about their motor sport they are engaged in. However, their information needs are often oneoff with clear start and end points. When they find the required information, their need is satisfied. As such, enthusiasts' information seeking is not intensive, ongoing or a continuing process of sense making and investigative research in contrast to family history/genealogy (Yakel, 2004) and food blogging research (Cox \& Blake, 2011) where the information seeking activity operates without a clear end goal. In addition, enthusiasts seek information to fulfil their information gap, problem or task, not to seek meaning or for self-identification or self-discovery as reported in genealogy research (Yakel, 2004).

The findings did not indicate enthusiasts' information needs on who their spectators, audiences or the public (PAP system) are, as in the case of food bloggers reported by Cox and Blake (2011, p. 216). Instead, the results indicate that motor sport enthusiasts are involved for their own leisure and for the gratification the sport offers for their participation. However, it is likely that sports promoters and event organisers are likely to be interested in knowing who the spectators are, where do they come from, which motor events they attend, etcetera.

Unlike the food bloggers (Cox \& Blake, 2011) who are creating and thus publishing content with the intention of attracting internet traffic to their blogs, enthusiasts were observed to create content to share with family and friends about their recent motor sport race events.

Enthusiasts stated that they sought travel logistics information, which included finding out and arranging their travels to motor sport events to compete and/or officiate. The current research did not ask about their travel information needs and sources they consulted before and after the travel. However, from Chang's (2009) research about backpackers need for information before and after travel and their use of different information sources at these stages, it can be assumed that this information behaviour would apply to motor enthusiasts, too.

\section{Limitations}

Given this was an exploratory study using an online survey, it was not possible to include a statistically representative sample, or to probe participants with further deeper questions to gain a comprehensive understanding of their information behaviour. Hence, when questions asked participants to rate their information seeking experience, it was not possible to probe further to find out why their experiences were unsatisfactory. Using interviews would have enabled robust and descriptive qualitative in-depth data thereby allowing for further probing and deeper investigation (Pickard, 2013). Future research involving interviews could be conducted, in particular as 52 participants $(69 \%)$ in this study provided an email address and stated their willingness to participate in future research. 
Further, as this research is restricted to one segment of the motor sport industry and focused on enthusiasts in Australia, it is acknowledged that the findings cannot be generalised to reflect the information behaviour of motor sport enthusiasts globally.

\section{Significance of this research}

This research contributes to the expanding scholarly research on people's everyday need, use, seeking, sharing and personal information management in their serious leisure pursuits, with a focus on motor sport. The typology of enthusiasts information needs (Table 8) is a significant contribution to the motor sport leisure activity.

This research is significant as it offers some original insights into two key areas. Firstly, it is the first research to investigate the leisure information needs and practices of motor sport enthusiasts. Secondly, it is the first study to provide a preliminary motor sport information behaviour model for this community and this serious leisure activity (Figure 3 ).

Another significance of this research is that it further confirms that the seminal information behaviour research models of Wilson (1984, 1999, 2000), Krikelas (1983), Dervin (1992), and (Savolainen, 1995a, 1995b, 1995c) developed prior to the availability of social media sources are still relevant and can be applied to understanding serious leisure activities information behaviour.

This research further highlighted that the medium for information seeking generally has shifted from traditional paper-based sources to more electronic and web-based sources. Social media and web technologies, text messages and emails have enabled easier, faster and instant information communication, sharing, searching and retrieval, compared to traditional sources. Additionally, patterns for seeking information from human resources has changed from the traditional face-to-face interaction with people to online interactions with human resources using text messaging, emails and social media technologies.

The final significance of this research is that it highlights that motor sport enthusiasts generate, capture and maintain considerable personal information about their involvement in the sport. A high proportion of these information assets are stored in electronic format. They also share this information electronically with their family and friends. These findings should alert information management professionals in cultural institutions like the national libraries, archives and museums about the information risks of these electronic information assets in the hands of novice citizens, who may not be aware of the fragility of electronic information. Or be skilled in ensuring the long-term preservation of their personal information assets before technological, software and format obsolescence sets in. It signifies the need for cultural institutions to visibly step-in with services provisions for the management of community-based information assets or community archives. How can these memory institutions sustainably capture the information assets of its citizens into their cultural repositories before it is lost or deteriorates? Or are there expectations that individual leisure communities will sustainably manage their community archives?

\section{Future research}


This exploratory research needs to be validated with in-depth interview sessions with up to 24 enthusiasts so that deeper understanding of their information behaviour can be gained (Miles \& Huberman, 1994). Additionally, five future research topics have been identified from this research.

The first is regarding what types and how frequently enthusiasts share their information on motor sport.

The second relates to what information sources enthusiasts preferred to satisfy their information needs. This study investigated which information sources enthusiasts used to satisfy their information needs but not what information sources they preferred. Hence, it would be worthwhile investigating whether they used Savolainen and Kari's (2004, p. 418) seven relevance judgement criteria to facilitate their everyday life information seeking: experience from use of previous information sources; situation demands on information seeking; perceived network competence; and perceived accessibility and quality of information sources.

The third relates to how enthusiasts are managing their personal information and to assess if it is indeed managed to best practice standards for archival collections. How do they manage their collections at home? Do they manage them electronically? If so what systems do they use? How are they managing their paper based collections? Is it being digitised? If yes, how are digital copies managed and are originals discarded or retained? Is there a system for filing or classifying like information together? Research into these questions will provide an opportunity to engage with the wider literature on personal information management (Jones \& Teevan, 2007). It would also determine whether an appraisal exercise is required to categorise their information as records of ephemeral, temporary and permanent archival value.

The fourth future research relates to this comment by a participant on how they manage their personal information: 'My results are available on Natsoft and Facebook is available for anything else I want to share with the public'. Natsoft is a third party database that captures motor sport race results in Australia. This comment highlights that citizens are using and turning to Facebook as an archival repository for their life history. Future research needs to be conducted to establish how true this phenomenon is and then assess the implications for cultural institutions. Should information management professionals start a dialogue with social media providers like Facebook to capture citizen's personal life histories, which forms family history information back into cultural repositories? Is Facebook becoming the new ancestry.com for citizen's family history repository and therefore family history research?

The fifth and final topic relates to enthusiasts' travel logistics information, which included finding out and arranging their travels to motor sport events to compete and/or officiate. The current research did not ask about their travel information needs and sources they consulted before and after travel. Future research could explore motor sport enthusiasts' need for information on travel and whether the variety of sources consulted before, during and after travel matched the stages found in Chang's (2009) research on the information needs of backpackers.

\section{Conclusion}

This study explored the information behaviour of motor sport enthusiasts in Australia, and contributes to the growing body of literature on information in leisure or non-work settings. 
This research has substantiated that motor sport is a serious leisure activity (Stebbins, 2007) and since some participants engaged in multiple roles in the sport it is a mixed serious leisure activity (Stebbins, 2007, p. 34). The preliminary motor sport information behaviour model (Figure 3) summarises enthusiasts' leisure information behaviour.

As the populations in developed nations age (Australian Bureau of Statistics, 2014) and people have more time to engage in leisure activities (Chang, 2009), more information related to their leisure activities is likely to be generated, requested and shared. This circumstance will have implications for the provision of library, archives and museum services. In the case of motor sport's information assets, their community and individual enthusiasts' archives may need to be deposited at various cultural institutions: the physical motor car to the museum; photos, sport diaries, memorabilia to local history library collections or the state/national archives. This increase in community archives has implications for cultural institutions to devise strategies to capture citizens' social leisure historical archives in electronic and paper formats, physical artefacts and published on social media websites like FaceBook and Flickr, for example.

It is hoped that the understanding gained from this research on enthusiasts' information behaviour would assist motor car clubs and CAMS when planning motor activities for their members and when considering systems to manage the motor sport community's archives and history.

\section{[Insert Appendix 1]}

\section{References}

Australian Bureau of Statistics. (2012), Sport and recreation: A statistical overview, Australia (No. 4156.0), Canberra, ACT, available at: http://www.ausstats.abs.gov.au/Ausstats/subscriber.nsf/0/6E28777ED2896A2BCA25 7AD9000E2FC5/\$File/41560_2012.pdf.

Author. (in review-a). Records management practices in historic motor sport: A single case study in Western Australia, Witheld, being peer reviewed, (?)(?).

Author. (in review-b). Leisure and information practices: A case study of motor sport in Australia. Witheld, being peer reviewed, (?)(?).

Bates, M. J. (1979). Information search tactics. Journal of the American Society for Information Science, 30(4), 205-214, available at: http://proquest.umi.com.dbgw.lis.curtin.edu.au/pqdweb?did $=639246401 \& \mathrm{Fmt}=7 \& \mathrm{cli}$ entId $=22212 \& R Q T=309 \&$ VName $=$ PQD $($ accessed 13 January 2010).

Bates, M. J. (1984). The fallacy of the perfect thirty-item online search. Reference Quarterly, 24(1), 43-50.

Bates, M. J. (1989). The design of browsing and berrypicking techniques for the online search interface. Online Review, 13(5), 407-424.

Belkin, N., J. (1980). Anomalous states of knowledge as a basis for information retrieval. Canadian Journal of Information Science, 5, 133-143, available at: http://acta.uta.fi (accessed 13 January 2010).

Belkin, N., J., Brooks, H. M., \& Oddy, R. N. (1982). ASK for information retrieval. Journal of Documentation, 38(2), 61-71. 
Braun, V. and Clarke, V. (2006), "Using thematic analysis in psychology", Qualitative Research in Psychology, Vol. 3, No. 2, pp. 77-101.

Brine, A. and Feather, J. (2010), "The information needs of UK historic houses: Mapping the ground", Journal of Documentation, Vol. 66, No. 1, pp. 28-45.

Bystrom, K. (2005). Information activities in work tasks. In K. E. Fisher, S. Erdelez, \& L. E. F. McKechnie (Eds.), Theories of information behavior (pp. 174-178). New Jersey: Information Today Inc.

Bystrom, K., \& Hansen, P. (2005). Conceptual framework for tasks in information studies. Journal of the American Society for Information Science, 56(10), 1050-1062.

Bystrom, K., \& Jarvelin, K. (1995). Task complexity affects information seeking and use. Information Processing and Management, 31(2), 191-213.

Case, D. (2002). Looking for information: A survey of research on information seeking, needs, and behaviour. London: Academic Press.

Case, D. (2005). Principle of least effort. In K. E. Fisher, S. Erdelez, \& L. E. F. McKechnie (Eds.), Theories of Information Behavior (pp. 289-292). USA: American Society for Information Science and Technology (ASIS\&T).

Case, D. (2010), "A model of the information seeking and decision making of online coin buyers", Information Research, Vol. 15, No. 4, available at: http://InformationR.net/ir/15-4/paper448.html (accessed 17 May 2014).

Case, D. (2012). Looking for information: A survey of research on information seeking, needs, and behaviour (3rd Edition ed.). London: Emerald Group Publishing Limited.

Chang, S. L. (2009), "Information research in leisure: Implications from an empirical study of backpackers", Library Trends, Vol. 57, No. 4, pp. 711-728.

Chen, C. and Hernon, P. (1982), Information seeking: Assessing and anticipating user needs, Neal-Schuman, New York.

Cole, C. (2012). Information need: A theory connecting information search to knowledge formulation. New Jersey, USA: Published on behalf of the American Society for Information Science and Technology by Information Today, Inc.

Cox, A. M. and Blake, M. K. (2011), "Information and food blogging as serious leisure", Aslib Proceedings: New Information Perspectives, Vol. 63, No. 2/3, pp. 204-220.

Cox, A. M., Clough, P. D. and Marlow, J. (2008), "Flickr:A first look at user behaviour in the context of photography as serious leisure". Information Research, Vol. 13, No. 1.

Creswell, J. W. (2013), Qualitative inquiry and research design: Choosing among five approaches (3rd ed.), SAGE Publications, London.

Dannefer, D. (1980), "Rationality and passion in private experience: Modern consciousness and the social world of old car collectors", Social Problems, Vol. 27, No. 4, pp. 392412.

Dannefer, D. (1981), "Neither socialization nor recruitment: The avocational careers of oldcar enthusiasts", Social Forces, Vol. 60, No. 2, pp. 395-413.

Debowski, S. (1997). The impacts of guided mastery training, self-efficacy and feedback on effort, search strategy and performance while conducting complex information search tasks. (Doctor of Philosophy PhD Thesis), University of Western Australia, Perth

Dervin, B. (1976), The everyday information needs of the average citizen: a taxonomy for analysis In M. Kochen, D., (Ed.), Information for the Community (pp. 19 -38), American Library Association, Chicago, IL.

Dervin, B. (2005). What methodology does to theory: Sense-making methodology as exemplar. In K. E. Fisher, S. Erdelez, \& L. E. F. McKechnie (Eds.), Theories of Information Behavior (pp. 25 - 29). New Jersey: Information Today Inc.

Dervin, B. (Ed.) (1992). From the mind's eye of the user: The sense-making qualitative methodology. Englewood, CO: Libraries Unlimited. 
Dervin, B., \& Foreman-Wernet, L. (Eds.). (2003). Sense-making methodology reader: Selected writings of Brenda Dervin. Cresskill, NJ: Hampton Press.

Ellis, D. (1984). Theory and explanation in information retrieval research. Journal of Information Science, 8(1), 25-39.

Ellis, D. (1989). A behavioral approach to information retrieval system design. Journal of Documentation, 45(3), 171-212.

Ellis, D. (1993). Modelling the information-seeking patterns of academic researchers: A grounded theory approach. Library Quarterly, 63, 469-486.

Ellis, D. (Ed.) (2003). Information-seeking behaviour. London, UK: Routledge.

Fisher, K. E., Erdelez, S., \& McKechnie, L. E. F. (Eds.). (2005). Theories of Information Behavior: A Researcher's Guide. New Jersey: Information Today Inc.

Fulton, C. (2009), "The pleasure principle: The power of positive affect in information seeking”, Aslib Proceedings: New Information Perspectives, Vol. 61, No. 3, pp. 245261.

Gainor, R. (2009), "Leisure information behaviours in hobby quilting sites", Paper presented at the Mapping the Twenty-first Century Information Landscape: Borders, Bridges and Byways, Carleton University, Ottawa, 28-30 May.

Gorman, G. and Clayton, P. (2005), Qualitative research for the information professional: A practical handbook (2nd ed.), Facet Publishing, London.

Hartel, J. (2006), "Information activities and resources in an episode of gourmet cooking", Information Research, Vol. 12, No. 1, available at: http://informationr.net/ir/121/paper282.html (accessed 17 May 2014).

Hartel, J. (2010), "Managing documents at home for serious leisure: a case study of the hobby of gourmet cooking", Journal of Documentation, Vol. 66, No. 6, pp. 847-874.

Hastings, D. W., \& Cable, S. (2005). The globalization of a minor sport: The diffusion and commodification of masters swimming. Sociological Spectrum, 25, 133-154.

Henefer, J., \& Fulton, C. (2005). Krikelas's model of information seeking. In K. E. Fisher, S. Erdelez, \& L. E. F. McKechnie (Eds.), Theories of information behavior (pp. 225229). New Jersey: Information Today Inc.

Ingwersen, P. (1982). Search procedures in the library - analysed from the cognitive point of view. Journal of Documentation, 38(3), 165-191.

Ingwersen, P. (1992). Information retrieval interaction. London: Taylor Graham.

Ingwersen, P. (1996). Cognitive perspectives on information retrieval interaction: Elements of a cognitive IR theory. Journal of Documentation, 52, 3-50.

Ingwersen, P. (2001). Cognitive information retrieval. Annual Review of Information Science and Technology, 34, 3-51.

Ingwersen, P. (2005). Integrative framework for information seeking and interactive information retrieval. In K. E. Fisher, S. Erdelez, \& L. E. F. McKechnie (Eds.), Theories of Information Behavior (pp. 215-220). USA: American Society for Information Science and Technology (ASIS\&T).

Jones, W. and Teevan, J. (Eds.), (2007), Personal information management. University of Washington Press, London, United Kingdom.

Joseph, P. (2010). EDRMS search behaviour: Implications for records management principles and practices. (Doctor of Philosophy PhD Thesis), University of Western Australia, Perth

Krikelas, J. (1983). Information-seeking behavior: Patterns and concepts. Drexel Library Quarterly, 19, 5-20.

Kuhlthau, C. C. (1988). Perceptions of the information search process in libraries: A study of changes from high school through college. Information Processing and Management, 24(4), 419-427. 
Kuhlthau, C. C. (1993). Seeking meaning: A process approach to library and information services. Norwood, NJ: Ablex.

Kuhlthau, C. C. (1999). Accommodating the user's information search process: Challenges for information retrieval systems designers. Bulletin of the American Society for Information Science, 25(3), 12-16.

Kuhlthau, C. C. (2004). Seeking meaning: A process approach to library and information services. Westport, CT: Libraries Unlimited.

Kuhlthau, C. C. (2005). Kuhlthau's information search process. In K. E. Fisher, S. Erdelez, \& L. E. F. McKechnie (Eds.), Theories of information behavior (pp. 230-234). New Jersey: Information Today Inc.

Lee, C. P. and Trace, C. B. (2009), "The role of information in a community of hobbyist collectors", Journal of the American Society for Information Science and Technology, Vol. 60, No. 3, pp. 621-637.

Maclean, B., \& Shipman, A. (2003). PD 0025: Britain's best selling guide to ISO 15489. Informaa Quarterly, 19(2), 18-20.

Margree, P., MacFarlane, A., Price, L., \& Robinson, L. (2014, 10 December 2014). Information behaviour of music record collectors. Information Research, available at: http://www.informationr.net/ir/19-4/paper652.html\#.VmawasqjTqs (accessed 10 December 2014).

Miles, M. B. and Huberman, A. M. (1994), Qualitative data analysis. Thousand Oaks, California.

Pickard, A. J. (2013), Research methods in information (2nd ed.), Facet Publishing, London.

Prigoda, E. and McKenzie, P. (2007), "Purls of wisdoms: A collectivisit study of human behaviour in a public library", Journal of Documentation, Vol. 63, No. 1, pp. 90-114.

Ross, C. S. (1999), "Finding without seeking: The information encounter in the context of reading for pleasure", Information Processing \& Management, Vol. 35, No. 6, pp. 783-799.

Saracevic, T. (1997). The stratified model of information retrieval interaction: Extension and applications. Paper presented at the American Society for Information Science Annual Meeting, November 1-6, 1997, Washington, DC.

Savolainen, R. (1995a), "Everyday life information seeking: A comparative study of the everyday life seeking of industrial workers and teachers in the context of way of life", University of Tampere, Department of Information Studies, Tampere, Finland.

Savolainen, R. (1995b), "Everyday life information seeking: Approaching information seeking in the context of "way of life"', Library \& Information Science Research, Vol. 17, No. 3, pp. 259 - 294.

Savolainen, R. (1995c). Everyday life information seeking: Findings and methodological questions of an empirical study. Paper presented at the The 1st British-Nordic Conference on Library and Information Studies, Copenhagen, The Royal School of Librarianship.

Savolainen, R. and Kari, K. (2004), "Placing the internet in information source horizons. A study of information seeking by internet users in the context of self-development", Library \& Information Science Research,Vol. 26, pp. 415-433, available at:http://www.sciencedirect.com.dbgw.lis.curtin.edu.au/science/article/pii/S07408188 $\underline{04000520}$ (accessed 16 December 2014).

Skov, M. (2013), "Hobby-related information-seeking behaviour of highly dedicated online museum visitors". Information Research, Vol. 18, No. 4, available at: http://www.informationr.net/ir/18-4/paper597.html\#.UzPx6IVdBns (accessed 8 January 2014). 
Spink, A., \& Saracevic, T. (1997). Interactive information retrieval: Sources and effectiveness of search terms during mediated online searching. Journal of the American Society for Information Science, 48, 741-761.

Stebbins, R. A. (2001), New directions in the theory and research of serious leisure (Vol. 28), The Edwin Mellen Press Ltd, Wales.

Stebbins, R. A. (2007), Serious leisure: A perspective for our time. Transaction Publishers, New Brunswick, N.J.

The Confederation of Australian Motor Sport Limited. (2014), Economic contribution of the Australian motor sport industry, available at: http://docs.cams.com.au/Public\%20Documents/CAMS_EYReport_201014_LR.pdf, (accessed 22 December 2014).

The Confederation of Australian Motor Sport Limited. (n.d.), History, available at: https://www.cams.com.au/about/about-cams/history (accessed 19 June 2014).

Vakkari, P. (1999). Task complexity, problem structure and information actions: Integrating studies on information seeking and retrieval Information Processing and Management, 35(6), 819-837.

Vakkari, P. (2003). Task-base information searching. Annual Review of Information Science and Technology, 37(1), 413-464.

Wersig, G. (1979). The problematic situation as basis concept of information science in the framework of the social sciences In theoretical problems for informatics: new trends in informatics and its terminology (pp. 48-57). Moscow: International Federation for Documentation.

Wersig, G. (1985). Information science needs a theory of "information actions". Social Science Information Studies, 5, 11-23.

Wilson, T. D. (1984). The cognitive approach to information-seeking behaviour and information use. Social Science Information Studies, 4(2/3), 197-204.

Wilson, T. D. (1999). Models in information behavior research. Journal of Documentation, $55(3), 249-270$.

Wilson, T. D. (2000). Human information behaviour. Information Science Research, 3(2), 4956, available at: http://ptarpp2.uitm.edu.my/ptarpprack/silibus/is772/HumanInfoBehavior.pdf (accessed 20 December 2014).

Yakel, E. (2004), “Seeking information, seeking connections, seeking meaning: genealogists and family historians", Information Research, Vol. 10, No. 1, available at: http://InformationR.net/ir/10-1/paper205.html (accessed 15 March 2013). 
Figure 1: Pyramid metaphor to describe motor racing internationally

Figure 2: Q11 Please rate your satisfaction level for each of the following regarding your interest in motor sport.

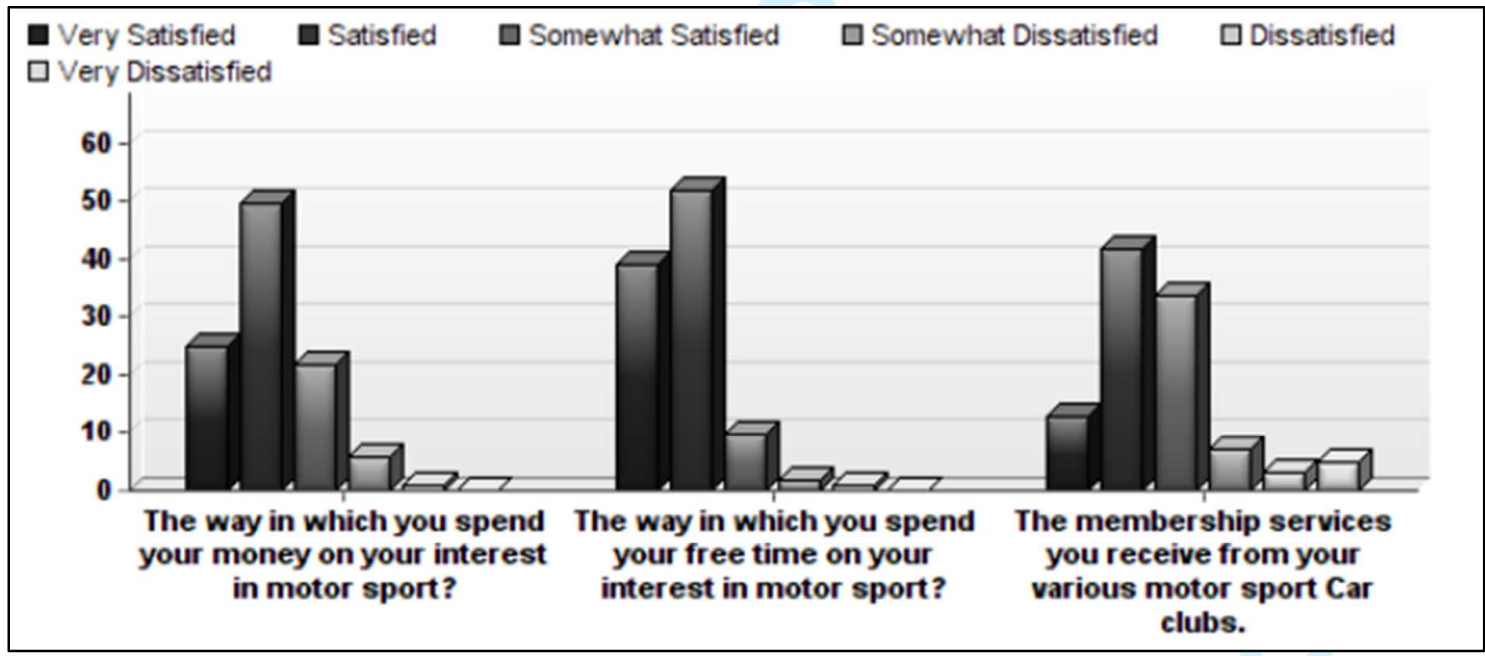


Figure 3: preliminary Motor Sport Information Behaviour Model

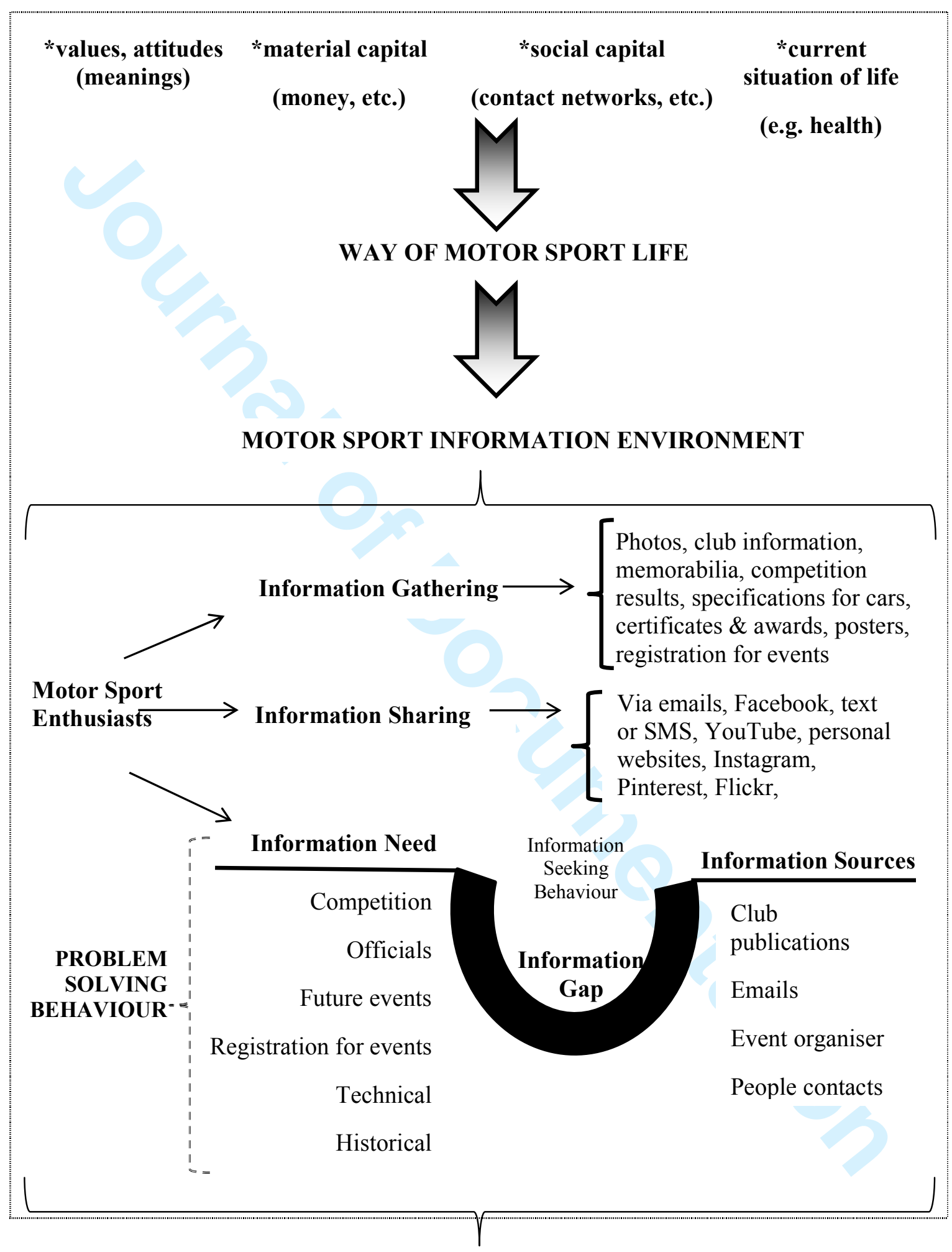


Table 1: Summary of literature review on information seeking behaviour in leisure activities

\begin{tabular}{|c|c|c|c|c|c|c|}
\hline \multirow[t]{2}{*}{ Source } & \multirow{2}{*}{$\begin{array}{l}\text { Leisure } \\
\text { activity }\end{array}$} & \multirow{2}{*}{$\begin{array}{l}\text { Serious leisure } \\
\text { (Stebbins, } \\
\text { 1992, 1994, } \\
\text { 2001, 2007) }\end{array}$} & \multirow[b]{2}{*}{ Research Aim/s: } & \multicolumn{3}{|c|}{ Research methodology } \\
\hline & & & & Method & $\begin{array}{l}\text { Sample } \\
\text { size }\end{array}$ & Location \\
\hline (Ross, 1999) & Leisure reading & Hobbyist & $\begin{array}{l}\text { To find out how readers choose books to read for pleasure } \\
\text { and how books made a significant difference in reader's } \\
\text { lives. }\end{array}$ & Interviews & 194 & Canada \\
\hline (Yakel, 2004) & Genealogy & Hobbyist & $\begin{array}{l}\text { What are the information seeking patterns of genealogists } \\
\text { and how do they manage their research information? }\end{array}$ & Semi-structured hour long interviews & 29 & $\begin{array}{l}\text { United } \\
\text { States }\end{array}$ \\
\hline $\begin{array}{c}\text { (Hartel, 2003, } \\
2005,2006,2010)\end{array}$ & $\begin{array}{l}\text { Gourmet } \\
\text { cooking }\end{array}$ & Hobbyist & $\begin{array}{l}\text { Study } 2 \text { information phenomena: information activities } \\
\text { and sources. }\end{array}$ & Semi-structured hour long interviews & 20 & $\begin{array}{l}\text { United } \\
\text { States }\end{array}$ \\
\hline (McKenzie, 2007) & Knitting & Hobbyist & $\begin{array}{l}\text { To 'apply a collectivist theoretical framework to the study } \\
\text { of human information behaviour and the construction of } \\
\text { meaning in a knitting group' (p.90). }\end{array}$ & $\begin{array}{l}\text { Participant observation of } 5 \text { sessions of a } \\
\text { group. Each session had } 13 \text { to } 20 \text { women } \\
\text { and lasted about } 2 \text { hours. Plus semi-struc } \\
\text { interviews with } 12 \text { knitters. }\end{array}$ & $\begin{array}{l}\text { knitting } \\
\text { knitters } \\
\text { tured }\end{array}$ & Canada \\
\hline (Cox et al., 2008) & Photography & Amateur & $\begin{array}{l}\text { An examination of user behaviour of amateur } \\
\text { photographers on Flickr. }\end{array}$ & $\begin{array}{l}\text { Open-ended } 30 \text { to } 40 \text { mins telephone } \\
\text { interviews. }\end{array}$ & 11 & $\begin{array}{c}\text { United } \\
\text { Kingdom }\end{array}$ \\
\hline (Chang, 2009) & Backpackers & Hobbyist & $\begin{array}{l}\text { Explore how backpackers collect and search for } \\
\text { information to plan their travel experiences. }\end{array}$ & $\begin{array}{l}\text { Semi-structured hour long interviews } \\
\text { and a brief questionnaire for } \\
\text { demographic data. }\end{array}$ & 30 & Taiwan \\
\hline (Fulton, 2009) & Genealogy & Amateur & $\begin{array}{l}\text { Investigated the 'positive affect and the significant place } \\
\text { of pleasure in amateur genealogists' information seeking } \\
\text { and skills development' (Fulton, 2009, p. 246). }\end{array}$ & $\begin{array}{l}\text { Semi-structured } 30 \text { mins telephone } \\
\text { interviews }\end{array}$ & 24 & Global \\
\hline $\begin{array}{l}\text { (Lee \& Trace, } \\
\text { 2009) }\end{array}$ & $\begin{array}{l}\text { Rubber ducks } \\
\text { collection }\end{array}$ & Hobbyist & $\begin{array}{l}\text { Explore dimensions of collecting; develop a typology of } \\
\text { collectors; and model of information needs of this } \\
\text { collector community. }\end{array}$ & $\begin{array}{l}\text { Semi-structured } 30 \text { mins to hour long } \\
\text { interviews }\end{array}$ & 13 & $\begin{array}{l}\text { United } \\
\text { States \& } \\
\text { Europe }\end{array}$ \\
\hline $\begin{array}{l}\text { (Skov, 2009, } \\
\text { 2013) }\end{array}$ & $\begin{array}{l}\text { Online museum } \\
\text { visitors }\end{array}$ & Hobbyist & $\begin{array}{l}\text { How can online museum visitors be categorised within } \\
\text { Stebbins's taxonomy of classes of serious leisure pursuit? } \\
\text { What characterises the information behaviour of online } \\
\text { museum visitors? }\end{array}$ & $\begin{array}{l}\text { Web questionnaire survey (130) \& } \\
\text { interviews with } 20 \text { participants. }\end{array}$ & 150 & Denmark \\
\hline (Gainor, 2009) & Quilting & Hobbyist & $\begin{array}{l}\text { An examination 'of hobby quilting Web sites and blogs, } \\
\text { asking how creativity, virtual community, and expressed } \\
\text { motivations are involved in creation of information } \\
\text { resources' (Gainor, 2009, p. 1). }\end{array}$ & Reviewed 25 public domain websites. & & Global (?) \\
\hline (Case, 2010) & Coin collection & Hobbyist & $\begin{array}{l}\text { Explore collecting as serious leisure using coin collecting } \\
\text { as an example. }\end{array}$ & $\begin{array}{l}\text { Moderate participant observation of coin } \\
\text { collectors in } 7 \text { action scenes, about } 1,100 \\
\text { collectors. }\end{array}$ & & $\begin{array}{l}\text { United } \\
\text { States }\end{array}$ \\
\hline $\begin{array}{l}\text { (Cox \& Blake, } \\
\text { 2011) }\end{array}$ & Food blogging & Hobbyist & $\begin{array}{l}\text { Explore creating, seeking, sharing and personal } \\
\text { information management. }\end{array}$ & In-depth hour long interviews & 6 & $\begin{array}{c}\text { United } \\
\text { Kingdom }\end{array}$ \\
\hline $\begin{array}{l}\text { (Margree et al., } \\
\text { 2014) }\end{array}$ & $\begin{array}{l}\text { Music record } \\
\text { collectors }\end{array}$ & Hobbyist & $\begin{array}{l}\text { Exploration of the information behaviour of music record } \\
\text { collectors. }\end{array}$ & $\begin{array}{l}\text { In-depth semi-structured hour long } \\
\text { interviews }\end{array}$ & 8 & $\begin{array}{c}\text { United } \\
\text { Kingdom }\end{array}$ \\
\hline
\end{tabular}


Table 2: Structure of online survey questions

\begin{tabular}{|c|l|c|}
\hline \multicolumn{1}{|c|}{ Survey Segments } & Questions \\
\hline 1 & About you (demographic information) & $1-11$ \\
\hline 2 & Your information needs and seeking behaviour & $12-16$ \\
\hline 3 & Personal information management & $17-20$ \\
\hline 4 & Your information needs from CAMS & $21-29$ \\
\hline 5 & Scenario of CAMS providing a central repository & $30-33$ \\
\hline
\end{tabular}

Table 3: Q5 Which motor sport discipline do you compete in? Tick as many of the options below that apply.

\begin{tabular}{|l|c|c|c|}
\hline \multirow{2}{*}{ Answer } & & $\begin{array}{c}\text { Response } \\
\mathrm{n}=74\end{array}$ & $\mathbf{\%}$ \\
\hline Speed & & 37 & 50 \\
\hline Race (Circuit) & & 29 & 39 \\
\hline Rally & & 29 & 39 \\
\hline Social & & 25 & 34 \\
\hline Historic Groups & 22 & 30 \\
\hline Regularity/Trial & & 20 & 27 \\
\hline Auto-test & & 15 & 20 \\
\hline Off-Road & & 8 & 11 \\
\hline
\end{tabular}

Table 4: Q7 What is/are/were your involvement with motor sport?

\begin{tabular}{|c|c|c|}
\hline Answer & $\begin{array}{c}\text { Response } \\
n=104\end{array}$ & $\%$ \\
\hline $\begin{array}{l}\text { Volunteer for motor sport in the capacity of a scrutineer, cl } \\
\text { of course, steward of a meeting, flag marshal, or any other } \\
\text { official's role on the day of the race meeting event }\end{array}$ & 68 & 65 \\
\hline Spectator of motor sport & 66 & 63 \\
\hline Committee member for your sporting car club/s or CAMS & 47 & 45 \\
\hline Volunteer in other ways, please specify & 25 & 24 \\
\hline Other, please specify & 24 & 23 \\
\hline Spouse, partner, family, friend of a motor sport competitor & 23 & 22 \\
\hline Historian researching about motor sport & 14 & 13 \\
\hline
\end{tabular}


Table 5: Q12 What information needs related to your interest in motor sport do you have? Tick as many of the options below.

\begin{tabular}{|l|c|c|}
\hline \multicolumn{1}{|c|}{ Answer } & $\begin{array}{c}\text { Response } \\
\text { (n=100) }\end{array}$ & $|\%|$ \\
\hline $\begin{array}{l}\text { What are the upcoming competitions - what, where, when, } \\
\text { format (hill climb, regularity, race, sprint, etc.) so that I can } \\
\text { consider registering for the event. }\end{array}$ & 80 & 80 \\
$\begin{array}{l}\text { Competition information - regulations, scrutineering, when, } \\
\text { where and time for my drivers' briefings, safety highlights, } \\
\text { race results, }\end{array}$ & 69 & 69 \\
\hline $\begin{array}{l}\text { Technical information - to fix, maintain, repair, restore, } \\
\text { upgrade, and/or modify the car. }\end{array}$ & 64 & 64 \\
$\begin{array}{l}\text { Logistics information - travel arrangements to venues, } \\
\text { organise transport and accommodation. }\end{array}$ & 47 & 47 \\
\hline $\begin{array}{l}\text { Registration information for competitions - how to register, } \\
\text { what registration forms need to be completed. }\end{array}$ & 46 & 46 \\
\hline $\begin{array}{l}\text { Social events - social events organised by my club or CAMS } \\
\text { that is of interest to me and my family and friends? }\end{array}$ & 44 & 44 \\
\hline $\begin{array}{l}\text { About the course itself - about and how the course venue is } \\
\text { arranged, e.g. video clips. }\end{array}$ & 40 & 40 \\
\hline \begin{tabular}{l} 
Other, please specify \\
\hline
\end{tabular} & 17 & 17 \\
\hline
\end{tabular}

Table 6: Q13 Generally how and what information sources do you use to find the information you need for your interest in motor sport? Tick as many of the options below.

\begin{tabular}{|l|c|c|}
\hline \multicolumn{1}{|c|}{ Answer } & $\begin{array}{c}\text { Response } \\
(\mathbf{n = 1 0 0 )}\end{array}$ & $\mid \mathbf{\%}$ \\
\hline $\begin{array}{l}\text { Keep up with what is going on by reading, watching and } \\
\text { listening about motor sport in the traditional information } \\
\text { sources like: newspapers; radio; television; magazines } \\
\text { and books }\end{array}$ & 68 & 68 \\
\hline $\begin{array}{l}\text { Contact fellow motoring enthusiasts by email, phone, } \\
\text { text messages, in person }\end{array}$ & & 61 \\
\hline $\begin{array}{l}\text { Contact the event organisers for competitions by email, } \\
\text { phone, text messages, in person }\end{array}$ & 59 & 59 \\
\hline $\begin{array}{l}\text { Subscribe and use social media tools like: blogs; } \\
\text { FaceBook sites; Flickr; Pinterest; Instagram, etc. }\end{array}$ & 58 & 58 \\
\hline $\begin{array}{l}\text { Read relevant information from the websites; } \\
\text { Wikipedia; YouTube, etc.; }\end{array}$ & 57 & 57 \\
\hline $\begin{array}{l}\text { Contact my motoring club by email, phone, text } \\
\text { messages, in person }\end{array}$ & 45 & 45 \\
\hline $\begin{array}{l}\text { Use the online motor sport forums to post my question } \\
\text { and get answers from there }\end{array}$ & 44 & 44 \\
\hline $\begin{array}{l}\text { Contact the CAMS by email, phone, in person } \\
\text { Contact family and friends by email, phone, text } \\
\text { messages, in person }\end{array}$ & 41 & 41 \\
\hline $\begin{array}{l}\text { View trade catalogues relevant to my car } \\
\text { Other, please specify }\end{array}$ & 38 & 38 \\
\hline
\end{tabular}


Table 7: Q15 How do you share information about your interest in motor sport with family, friends and fellow motor sport enthusiasts?

\begin{tabular}{|l|c|c|c|}
\multicolumn{1}{c|}{ Answer } & $\begin{array}{c}\text { Response } \\
(\mathrm{n}=90)\end{array}$ & $\%$ \\
\hline Email & 69 & 77 \\
\hline FaceBook & 49 & 54 \\
\hline Text or SMS & 42 & 47 \\
\hline Other, please specify & 33 & 37 \\
\hline YouTube & 11 & 12 \\
\hline My own website & 8 & 9 \\
\hline Instagram & 6 & 7 \\
\hline Pinterest & 3 & 3 \\
\hline Flickr & 2 & 2 \\
\hline
\end{tabular}


Table 8: Topics of enthusiasts' information needs

\begin{tabular}{|c|c|c|}
\hline \multicolumn{2}{|r|}{ Information Needs } & Description \\
\hline 1 & Competition information & $\begin{array}{l}\text { Information relating to on track activities- regulations, } \\
\text { scrutineering, when, where and time for my drivers' } \\
\text { briefings, safety highlights, race results, licence, vehicle } \\
\text { log book, visa, insurance. } \\
\text { Who is competing, what are the regulations, race results, } \\
\text { about pits at the events, eligibility for the categories, } \\
\text { apparel for the event, etc. }\end{array}$ \\
\hline 2 & Officials' information & $\begin{array}{l}\text { Information needed by volunteers performing various } \\
\text { officiating roles in motor sport. }\end{array}$ \\
\hline 3 & About future race events & $\begin{array}{l}\text { Calendar - what, where, when, format (hill climb, } \\
\text { regularity, race, sprint, etc.) about upcoming events so } \\
\text { that I can consider registering for the event. Everything } \\
\text { about the event, when, where, what time, for } \\
\text { competitors, officials, volunteers, spectators, etc. How } \\
\text { much the tickets cost? }\end{array}$ \\
\hline 4 & $\begin{array}{l}\text { Registration information for } \\
\text { competitions }\end{array}$ & $\begin{array}{l}\text { Competitor and vehicle documentation - how to } \\
\text { register, what registration forms need to be completed. }\end{array}$ \\
\hline 5 & Technical information & $\begin{array}{l}\text { To fix, maintain, repair, restore, upgrade, and modify } \\
\text { the car. }\end{array}$ \\
\hline 6 & $\begin{array}{l}\text { Current and historical information } \\
\text { about motor sport }\end{array}$ & $\begin{array}{l}\text { Information sources and content regarding the sport- } \\
\text { current and historic information about the motor sport, } \\
\text { library materials, newsletters, etc. }\end{array}$ \\
\hline 7 & Logistics information & $\begin{array}{l}\text { Travel arrangements to venues, organise transport and } \\
\text { accommodation }\end{array}$ \\
\hline 8 & $\begin{array}{l}\text { General information about motor } \\
\text { sport }\end{array}$ & $\begin{array}{l}\text { News type information (such as a current topic like why } \\
\text { Daniel Ricciado was disqualified in his first Grand Prix } \\
\text { event in Australia) or general information about when } \\
\text { motor sport events will be telecast, racing news, etc. }\end{array}$ \\
\hline 9 & Meeting dates for CAMS or Clubs & Agendas, minutes, timetabling, and scheduling \\
\hline 10 & About the course itself & $\begin{array}{l}\text { Physical attributes of the circuit- about and how the } \\
\text { course venue is arranged, e.g. video clips. What is the } \\
\text { weather at the course on race day? }\end{array}$ \\
\hline 11 & Event organisation & $\begin{array}{l}\text { Promoter- information that is required to organise race } \\
\text { events or social events by event organisers. }\end{array}$ \\
\hline 12 & Social events & $\begin{array}{l}\text { Information relating to non-competitive activities - } \\
\text { social events organised by my club or CAMS that is of } \\
\text { interest to me and my family and friends. }\end{array}$ \\
\hline
\end{tabular}


Table 9: Categorisation of enthusiasts' information sources

\begin{tabular}{|c|c|c|c|}
\hline \multicolumn{3}{|r|}{ Information Sources } & Frequency \\
\hline 1 & \multicolumn{2}{|c|}{ Club magazines, newsletters and bulletins } & 13 \\
\hline 2 & \multicolumn{2}{|c|}{ Email } & 14 \\
\hline 3 & \multicolumn{2}{|l|}{ Event organiser } & 3 \\
\hline 4 & \multicolumn{2}{|l|}{ People contact } & 11 \\
\hline 5 & \multicolumn{2}{|l|}{ Text or SMS } & 1 \\
\hline 6 & \multirow[t]{6}{*}{ Web sources } & Internet & 47 \\
\hline 7 & & CAMS website & 37 \\
\hline 8 & & Club or category website & 26 \\
\hline 9 & & Online trade catalogues & 2 \\
\hline 10 & & Online forums & 1 \\
\hline 11 & & My own website or racing team's website & 1 \\
\hline 12 & \multirow[t]{4}{*}{ Social media } & Facebook & 5 \\
\hline 13 & & Flickr & 1 \\
\hline 14 & & Instagram & 1 \\
\hline 15 & & Twitter & 1 \\
\hline
\end{tabular}

Table 10: Q17 What information about motor sport do you have at home?

\begin{tabular}{|c|c|c|}
\hline Answer & $\begin{array}{c}\text { Response } \\
(\mathrm{n}=91)\end{array}$ & $\%$ \\
\hline Photos about cars, events I attended, etc., & 78 & 86 \\
\hline $\begin{array}{l}\text { Club specific information like club newsletters, } \\
\text { minutes of meetings, etc. }\end{array}$ & 69 & 76 \\
\hline Trophies and other memorabilia & 65 & 71 \\
\hline Competition results & 60 & 66 \\
\hline Specifications for cars & 60 & 66 \\
\hline $\begin{array}{l}\text { Certificate of awards for my motor sport } \\
\text { achievements and contributions to motor sport }\end{array}$ & 58 & 64 \\
\hline Posters on motor sport & 57 & 63 \\
\hline $\begin{array}{l}\text { Club records and archives in my role as a } \\
\text { committee member or volunteer to assist the } \\
\text { club with organising a race event }\end{array}$ & 32 & 35 \\
\hline Registrations for competitions & 28 & 31 \\
\hline Other, please specify & 25 & 27 \\
\hline
\end{tabular}




\section{Appendix 1 - Online Survey}

\section{Information behaviour of motor sport enthusiasts}

Q1 Are you a motor sport enthusiast?

Yes (1)

O No (2)

If No Is Selected, Then Skip To End of Block

---- About you: (These set of questions are about who you are and your hobby and leisure interests in motor sport)

Q2 What is your gender?

Male (1)

Female (2)

Q3 How old are you?

Under 20 (1)

O 20-29 (2)

O $30-39$ (3)

O $40-49$ (4)

O $50-59(5)$

O $60-69(6)$

○ $70-79(7)$

O $80-89(8)$

○ 90-99 (9)

Q4 Are or were you a motor sport competitor?

Y Yes (1)

No (2)

If No Is Selected, Then Skip To What are your connections regarding y... 
Q5 Which motor sport discipline do you compete in? Tick as many of the options below that apply.

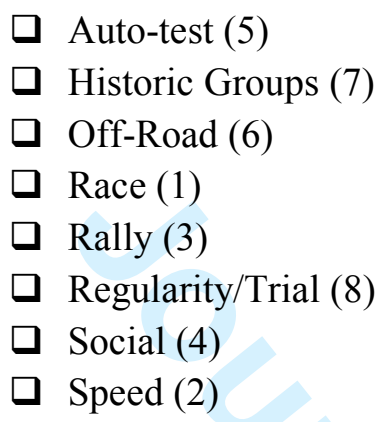

Q6 From your choice/s above please select the categories of the motor sport discipline that you compete in. You need to hold down the CONTROL Key whilst making your multiple selections with your mouse.

All 57 categories listed on the CAMS website were listed as options and omitted here owing to word limit for the article.

Q7 What is/are/were your involvement with motor sport? Tick as many of the options below that apply.

Volunteer for motor sport in the capacity of a Scrutineer, Clerk of Course, Steward of a Meeting, Flag Marshal, or any other Official's role on the day of the race meeting event (2)

Volunteer in other ways, please specify (3)

$\square$ Historian researching about motor sport (9)

Committee member for your sporting car club/s or CAMS (5)

$\square$ Spectator of motor sport (6)

Spouse, partner, family, friend of a motor sport competitor (7)

$\square$ Other, please specify (8)

Q8 How did you develop an interest in motor sport?

Q9 How long have you had an interest in motor sport?

Less than a year (1)

O 2-3 years $(2)$

O 5-10 years (3)

O 11-20 years (4)

21-30 years (5)

Other, please specify (6) 
Q10 How much time would you spend each week engaged with things or matters involving motor sport?

Between 1 to 5 hours in a week (5)

Between 6 to 10 hours in a week (6)

Between 10 to 50 hours in a week (7)

Other, please specify (8)

Q11 Please rate your satisfaction level for each of the following regarding your interest in motor sport.

\begin{tabular}{|c|c|c|c|c|c|c|}
\hline & $\begin{array}{c}\text { Very } \\
\text { Satisfied } \\
(25)\end{array}$ & $\begin{array}{l}\text { Satisfied } \\
\text { (26) }\end{array}$ & $\begin{array}{c}\text { Somewhat } \\
\text { Satisfied (27) }\end{array}$ & $\begin{array}{c}\text { Somewhat } \\
\text { Dissatisfied } \\
\text { (28) }\end{array}$ & $\begin{array}{l}\text { Dissatisfied } \\
\text { (29) }\end{array}$ & $\begin{array}{c}\text { Very } \\
\text { Dissatisfied } \\
\text { (30) }\end{array}$ \\
\hline $\begin{array}{l}\text { The way in } \\
\text { which you } \\
\text { spend your } \\
\text { money on } \\
\text { your } \\
\text { interest in } \\
\text { motor } \\
\text { sport? (1) }\end{array}$ & 0 & 0 & 0 & 0 & 0 & 0 \\
\hline $\begin{array}{l}\text { The way in } \\
\text { which you } \\
\text { spend your } \\
\text { free time on } \\
\text { your } \\
\text { interest in } \\
\text { motor } \\
\text { sport? (2) }\end{array}$ & 0 & 0 & 0 & 0 & 0 & 0 \\
\hline $\begin{array}{l}\text { The } \\
\text { membership } \\
\text { services } \\
\text { you receive } \\
\text { from your } \\
\text { various } \\
\text { motor sport } \\
\text { Car clubs. } \\
\text { (4) }\end{array}$ & 0 & 0 & 0 & 0 & 0 & 0 \\
\hline
\end{tabular}

---- Your information needs and seeking behaviour: (The next set of questions is about your information needs in motor sport and how you seek this information) 
Q12 What information needs related to your interest in motor sport do you have? Tick as many of the options below.

Technical information - to fix, maintain, repair, restore, upgrade, and/or modify the car. (1)

What are the upcoming competitions - what, where, when, format (hill climb, regularity, race, sprint, etc.) so that I can consider registering for the event. (2)

Registration information for competitions - how to register, what registration forms need to be completed. (3)

About the course itself - about and how the course venue is arranged, e.g. video clips. (4)

L Logistics information - travel arrangements to venues, organise transport and accommodation. (5)

Competition information - regulations, scrutineering, when, where and time for my drivers' briefings, safety highlights, race results, (6)

- Social events - social events organised by my club or CAMS that is of interest to me and my family and friends? (7)

$\square$ Other, please specify (8)

Q13 Generally how and what information sources do you use to find the information you need for your interest in motor sport? Tick as many of the options below.

Keep up with what is going on by reading, watching and listening about motor sport in the traditional information sources like: newspapers; radio; television; magazines and books (10)

Read relevant information from the websites; Wikipedia; YouTube, etc.; (1)

口 Subscribe and use social media tools like: blogs; FaceBook sites; Flickr; Pinterest; Instagram, etc. (11)

View trade catalogues relevant to my car (2)

Use the online motor sport forums to post my question and get answers from there (3)

Contact family and friends by email, phone, text messages, in person (4)

Contact fellow motoring enthusiasts by email, phone, text messages, in person (5)

Contact my motoring club by email, phone, text messages, in person (6)

C Contact the Confederation of Australian Motor Sport (CAMS) by email, phone, in person (7)

$\square$ Contact the event organisers for competitions by email, phone, text messages, in person (8)

$\square$ Other, please specify (9)

Q14 Do you share information about your interest in motor sport with family, friends and fellow motor sport enthusiasts?

Y Yes (1)

No (2)

If No Is Selected, Then Skip To Please rate your satisfaction levels... 
Q15 How do you share information about your interest in motor sport with family, friends and fellow motor sport enthusiasts?

My own website (3)

Email (9)

$\square$ Text or SMS (10)

$\square$ FaceBook (1)

$\square$ YouTube (2)

Flickr (5)

Instagram (7)

$\square$ Pinterest (8)

Other, please specify (6)

Q16 Please rate your satisfaction levels for the last 3 information needs you had. E.g. Information need $=\mathrm{I}$ had to find out when the next race meeting is. E.g. Information source $=\mathrm{I}$ sought this information by browsing my club's website. State NA if you are unable to recall your information need, then select NA for the multiple choices for that row in the last column.

\begin{tabular}{|l|l|l|l|l|l|l|}
\hline & $\begin{array}{c}\text { Describe } \\
\text { what } \\
\text { information } \\
\text { you needed? }\end{array}$ & $\begin{array}{c}\text { Describe } \\
\text { what } \\
\text { information } \\
\text { sources you } \\
\text { checked? }\end{array}$ & \multicolumn{5}{l|}{ Rate your satisfaction level fulfilling your information need. } \\
& $\begin{array}{l}\text { Information } \\
\text { need (1) }\end{array}$ & $\begin{array}{l}\text { Information } \\
\text { Source (1) }\end{array}$ & $\begin{array}{l}\text { Satisfied } \\
(1)\end{array}$ & $\begin{array}{l}\text { Somewhat } \\
\text { satisfied } \\
(2)\end{array}$ & $\begin{array}{l}\text { Not } \\
\text { Satisfied } \\
(3)\end{array}$ & NA (4) \\
$\begin{array}{l}\text { Information } \\
\text { Need 1 (2) } \\
\text { Information }\end{array}$ & $\begin{array}{l}\text { Need 2 (3) } \\
\text { Information } \\
\text { Need 3 (4) }\end{array}$ & & 0 & 0 & 0 & 0 \\
\hline
\end{tabular}

Personal information management: (This section of questions is about you manage your personal motor sport information) 
Q17 What information about motor sport do you have at home? Tick as many of the options below.

Specifications for cars (1)

Club specific information like club newsletters, minutes of meetings, etc. (2)

Club records and archives in my role as a committee member or volunteer to assist the club with organising a race meeting, (3)

口 Photos about cars, events I attended, etc., (4)

$\square$ Registrations for competitions (5)

$\square$ Competition results (6)

Trophies and other memorabilia (7)

$\square$ Certificate of awards for my motor sport achievements and contributions to motor sport (8)

$\square$ Posters on motor sport (9)

$\square$ Other, please specify (10)

Q18 Please indicate the media and format of these information resources

Half paper and half electronic based (1)

Primarily paper based (2)

O Primarily electronic based (3)

Q19 Please rate your satisfaction level on how you are managing your personal information about your interest in motor sport at home.

\begin{tabular}{|l|c|c|c|c|c|c|}
\hline & $\begin{array}{c}\text { Very } \\
\text { Satisfied (25) }\end{array}$ & Satisfied (26) & $\begin{array}{c}\text { Somewhat } \\
\text { Satisfied (27) }\end{array}$ & $\begin{array}{c}\text { Somewhat } \\
\text { Dissatisfied } \\
(28)\end{array}$ & $\begin{array}{c}\text { Dissatisfied } \\
\text { (29) }\end{array}$ & $\begin{array}{c}\text { Very } \\
\text { Dissatisfied } \\
(30)\end{array}$ \\
\hline I am (1) & O & 0 & 0 & 0 & 0 & 0 \\
\hline
\end{tabular}

Q20 Would you like advice and assistance for managing these information resources?

O Yes (2)

O No (3) 